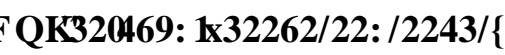

\title{
SAFETY EVALUATION OF SHIP'S MANEUVERS CARRIED OUT ON THE BASIS OF INTEGRATED NAVIGATION SYSTEMS (INS) INDICATIONS
}

\section{OCENA BEZPIECZEŃSTWA MANEWRÓW STATKU WYKONANYCH NA PODSTAWIE WSKAZAŃ ZINTEGROWANYCH SYSTEMÓW NAWIGACYJNYCH (ZSN)}

\author{
Arkadiusz Tomczak \\ Maritime University of Szczecin, Marine Traffic Engineering Institute \\ Akademia Morska, Instytut Inżynierii Ruchu Morskiego \\ 70-500 Szczecin, ul. Wały Chrobrego $1 / 2$ \\ e-mail: a.tomczak@am.szczecin.pl
}

\begin{abstract}
In the safety evaluation of maneuvers carried out on the basis of INS indications, the real ship's dimensions are used to determine navigation safety level. The paper presents a new approach to this problem. The ship's maneuvering area and collision probability were calculated incorporating uncertainty areas of ship's plan geometry at given probability level for typical configuration of navigational equipment applied in existing pilot systems. The widening coefficients of safety factors for each configuration set were determined and discussed.
\end{abstract}

Keywords: integrated navigation, safety of manoeuvring, uncertainty position,

Streszczenie: W artykule przedstawiono nowe podejście do problemu oceny bezpieczeństwa manewrów statku wykonanych na podstawie wskazań zintegrowanego systemu nawigacyjnego (ZSN). Przedstawiono metodę wyznaczania obszaru niepewności położenia statku prezentowanego w ZSN oraz wpływ wymiarów obszaru niepewności wyznaczonych dla różnych konfiguracji sprzętowych ZSN na bezpieczeństwo (prawdopodobieństwo wypadku, wielkość akwenu manewrowego).

Slowa kluczowe: nawigacja zintegrowana, bezpieczeństwo manewrów, GPS 


\section{SAFETY EVALUATION OF SHIP'S MANEUVERS CARRIED OUT ON THE BASIS OF INTEGRATED NAVIGATION SYSTEMS (INS) INDICATIONS}

\section{Introduction}

Presently integrated navigation systems are used more and more often as a basic source of navigation information while reduced visibility. The navigator analyse changes in arrangement of ship-environment based on integrated system indications, with no possibility of visual observation. In most of the cases it takes place on restricted water areas, where increased risk of accident exists. Basic information displayed in navigational systems consists of a graphical representation of ship's position in relation to navigational dangers (fig.1). Due to the method of determining the ship's position [1] as a geometrical object in a navigational system, this position is uncertain. Position uncertainty of ship's plan geometry is an area occupied horizontally by the ship whose dimensions can be determined by means of a probabilistic method at an adopted level of probability. The size of this area reflects uncertainty of defining ship's position in integrated navigation systems, while the distance of its boundaries in relation to navigational dangers may constitute a criterion of the assessment of the safety of maneuvers based on navigational system indications.

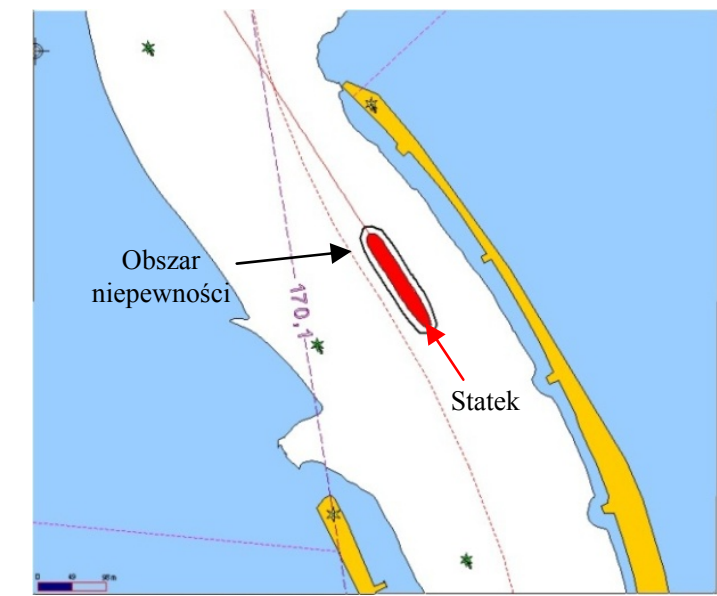

Fig. 1. The ship and her uncertainty area presented in navigation pilot system [2]. 
Taking into consideration the diversity of INS in the aspect of carried out of GPS measurement techniques (absolute GPS, differential GPS: DGPS, EGNOS, Real-time kinematic - RTK) [1], heading (GPS compass, gyrocompass) or local coordinates of GPS antenna location on the ship's deck it can be concluded that maneuvers carried out based on INS indications are distinguished by different safety level. From the point of INS based maneuvering safety evaluation, the relation between basic safety factors (dimensions of maneuvering area and probability of accident) and various configuration of navigation system is interesting. The safety evaluation problem of maneuvers carried out on basis of INS seems to be especially up to date in the light of worldwide research and the discussion in the European Union concerning the possibility of remote pilotage.

\section{Mathematical model of uncertainty area of ship's plan geometry}

One of the most important elements of combined measurement uncertainty assessment procedure is to define the formula for measurement result. Ship's location in INS can be determined based on following quotations:

$$
\begin{aligned}
& x_{r i}=x_{A r i}+d_{i} \sin \left(\psi_{r i}+\alpha_{i}\right) \\
& y_{r i}=y_{A r i}+d_{i} \cos \left(\psi_{r i}+\alpha_{i}\right)
\end{aligned}
$$

where: $x_{r i}, y_{r i}$ - calculated coordinates of consecutive points of ship's contour, $x_{A r i}, y_{A r i}$ recorded positions of GPS antenna - assuming north up orientation, $\psi_{r i}$ heading, $d_{i}$ - distance between GPS antenna and point of ship's contour, $\alpha_{i}$ angle between GPS antenna and point of ship's contour. The dimensions of uncertainty area of ship's plan geometry (fig.1) can be determined on the basis of "confidence ellipse of point location" quotations:

$$
\begin{aligned}
& A_{1-\alpha}=A \sqrt{\chi_{2,1-\alpha}^{2}} \\
& B_{1-\alpha}=B \sqrt{\chi_{2,1-\alpha}^{2}}
\end{aligned}
$$

where:

$$
\begin{aligned}
& A=\sigma\left(\alpha_{A}\right) \\
& B=\sigma\left(\alpha_{B}\right)
\end{aligned}
$$


The location error of consecutive point of ship's contour in $(\alpha)$ direction, arcing error curve, can be expressed as:

$$
\sigma(\alpha)=\sqrt{\sigma x_{r i}^{2} \cos ^{2} \alpha+\sigma x_{r i} y_{r i} \sin 2 \alpha+\sigma y_{r i}^{2} \sin ^{2} \alpha}
$$

The directions (azimuths) $\alpha_{A}$ and $\alpha_{B}$ were determined:

$$
\begin{aligned}
& \alpha_{A}=\frac{1}{2} \arctan \left(\frac{2 \sigma x_{r i} y_{r i}}{\sigma x_{r i}^{2}-\sigma y_{r i}^{2}}\right) \\
& \alpha_{B}=\alpha_{A}+\frac{\pi}{2}
\end{aligned}
$$

where: $\sigma x_{r i}^{2}-$ variance of $\mathrm{x}$ - coordinate of i-th ship's contour point, $\sigma y_{r i}^{2}$ variance of $\mathrm{x}$ - coordinate of $\mathrm{i}$-th ship's contour point, $\sigma x_{r i} y_{r i}$ - the covariance of (x, y-coordinates) of i-th ship's contour point, $A$ - semi major axis of error ellipse, $B$ - semi minor axis of error ellipse.

Based on general formula of uncertainty propagation theory the standard uncertainties of input values were determined and covariance matrix of twodimensional probability density function $\sigma_{\mathrm{F}}$ presents equitation (6):

$$
\sigma_{F}=\left[\begin{array}{llll}
\frac{\partial x_{r i}}{x_{A r i}} & \frac{\partial x_{r i}}{y_{A r i}} & \frac{\partial x_{r i}}{d_{i}} & \frac{\partial x_{r i}}{\gamma_{i}} \\
\frac{\partial y_{r i}}{y_{A r i}} & \frac{\partial y_{r i}}{x_{A r i}} & \frac{\partial y_{r i}}{d_{i}} & \frac{\partial y_{r i}}{\gamma_{i}}
\end{array}\right] \cdot\left[\begin{array}{cccc}
\sigma x_{A r i}^{2} & \sigma_{A r i} y_{A r i} & 0 & 0 \\
\sigma x_{A r i} y_{A r i} & \sigma y_{A r i}^{2} & 0 & 0 \\
0 & 0 & \sigma d_{i}^{2} & 0 \\
0 & 0 & 0 & \sigma \gamma_{i}^{2}
\end{array}\right] \cdot\left[\begin{array}{ll}
\frac{\partial x_{r i}}{x_{A r i}} & \frac{\partial y_{r i}}{y_{A r i}} \\
\frac{\partial x_{r i}}{y_{A r i}} & \frac{\partial y_{r i}}{x_{A r i}} \\
\frac{\partial x_{r i}}{d_{i}} & \frac{\partial y_{r i}}{d_{i}} \\
\frac{\partial x_{r i}}{\gamma_{i}} & \frac{\partial y_{r i}}{\gamma_{i}}
\end{array}\right]
$$

where: $\sigma x_{A r i}^{2}$-variance of latitude coordinate, $\sigma y_{A r i}^{2}$ - variance of longitude coordinate, $\sigma x_{A r i} y_{A r i}-$ covariance of latitude and longitude coordinates, $\sigma d^{2}{ }^{2}-$ variance of distance of i-th ship's contour point from antenna location, $\sigma \gamma^{2}{ }_{i}$ the sum of variances of angle $\alpha_{i}$ and heading $\psi_{i}$. 
Combined standard uncertainties of relevant consecutive points coordinate $\left(\sigma x_{r i}, \sigma y_{r i}\right)$ and its covariance $\sigma x_{r i} y_{r i}$ the directional errors were obtained from:

$$
\begin{aligned}
& \sigma x_{r i}^{2}=\sigma x_{A r i}^{2}+\sigma d_{i}^{2} \sin ^{2} \gamma_{i}+\sigma \gamma_{i}^{2} d^{2} \cos ^{2} \gamma_{i} \\
& \sigma y_{r i}^{2}=\sigma y_{A r i}^{2}+\sigma d_{i}^{2} \cos ^{2} \gamma_{i}+\sigma \gamma_{i}^{2} d^{2} \sin ^{2} \gamma_{i} \\
& \sigma x_{r i} y_{r i}=\sigma x_{A r i} y_{A r i}+\sigma d_{i}^{2} \sin \gamma_{i} \cos \gamma_{i}-\sigma \gamma_{i}^{2} d_{i}^{2} \sin \gamma_{i} \cos \gamma_{i}
\end{aligned}
$$

Providing above quotations to quotations (5) obtained directional vectors of errors of ship's contour points location:

$$
\begin{aligned}
& \alpha_{A}=\frac{1}{2} \arctan \\
& \left(\frac{2\left(\sigma x_{A r i} y_{A r i}+\sigma d_{i}^{2} \sin \gamma_{i} \cos \gamma_{i}-\sigma \gamma_{i}^{2} d_{i}^{2} \sin \gamma_{i} \cos \gamma_{i}\right)}{\left(\sigma x_{A r i}^{2}+\sigma d_{i}^{2} \sin ^{2} \gamma_{i}+\sigma \gamma_{i}^{2} d^{2} \cos ^{2} \gamma_{i}\right)-\left(\sigma y_{A r i}^{2}+\sigma d_{i}^{2} \cos ^{2} \gamma_{i}+\sigma \gamma_{i}^{2} d^{2} \sin ^{2} \gamma_{i}\right)}\right), \\
& \alpha_{B}=\alpha_{A}+\frac{\pi}{2}
\end{aligned}
$$

The example of uncertainty area determined according above algorithm, at 0,95 confidence level is presented on figure 3 .

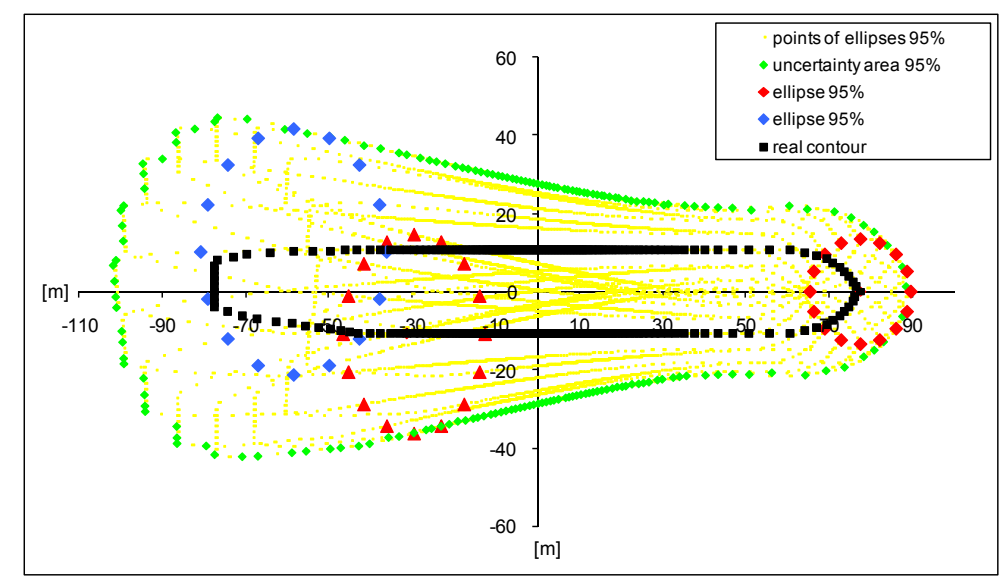

Figure 3. The uncertainty area of ship's plan geometry around the $\mathrm{m} / \mathrm{f}$ "Jan Śniadecki" contour formed after extreme points of error ellipse had been found for $95 \%$ confidence level and GPS antenna placed in fore part of the ship. 


\section{Safety evaluation of ship's manoeuvres carried out on the basis of pilot navigation system.}

The most essential problem in determining the restricted areas dimensions is to guarantee safety of navigation on this area. The designer of port, basin etc. is required to estimate risk of accident accompanying each specified ship's manoeuvres. The risk is defined as combination of probability of accident and its effects and can be expressed as:

$$
R=P_{A} \cdot S_{a}
$$

where : $R$ - risk of accident, $P_{A}$-probability of accident, $S_{a}$-effects of accident. For research purposes the risk value was assumed at $R=0,07$ level. By means of formula (12) the acceptable probability of accident $P_{a c c}=0,00019444$ was determined:

$$
P_{a c c .}=\frac{R_{a k c}}{I_{R} S_{a}}
$$

where: $I_{R}$-average intensity of particular manoeuvre in one year period (leaving port, turning, etc.). In order to examine ship's uncertainty area impact on the safety of manoeuvres executed according to indications of an integrated navigation system, a real experiment was carried out. In the experiment, m/f "Jan Śniadecki" performed 21 departure passages out of the port of Świnoujście. For the examined restricted area - a bend - the width of ship's swept path and probability of accident were chosen as criterions of safety assessment of passages. The boundaries of the navigable area for this region were defined by the $8 \mathrm{~m}$ depth contour on the starboard side and the crossing of that was assumed as an accident. Safety factors were determined for the different configuration of INS by means of precalculated uncertainty areas of "Jan Śniadecki" plan geometry. Particular variants of configuration are marked according to below description:

GPS_z - GPS autonomus and gyrocompass,

GPSSPS_z - GPS autonomus (accuracy published by Standard Positioning Service - SPS) and gyrocompass,

DGPSI_z - Differential GPS IALA\& gyrocompass,

DGPSICG(ng)_z - Differential GPS IALA (accuracy published by American Coast Guard - the worst case) \& gyrocompass,

DGPSI_GPSV - Differential GPS IALA \& compass GPS (CSI Vector). 
DGPSICG(ng)_GPSV - Differential GPS IALA(accuracy published by American Coast Guard - the worst case) \& compass GPS (CSI Vector), DGPSI_GPSVP - Differential GPS IALA \& compass GPS (CSI Vector), (accuracy published by manufacturer),

DGPSI_2DGPSI - Differential GPS IALA \& heading determined between two synchronically measuring DGPS receivers,

DGPSICG(nI)_ 2DGPSI - Differential GPS IALA(American Coast Guard - the best case) \& heading determined between two synchronically measuring DGPS receivers,

EGNOS_z - Differential GPS ( EGNOS corrections) \& gyrocompass, EGNOSSA(nI)_z - Differential GPS ( EGNOS corrections) (accuracy published by -European Space Agency: ESA the best case \& gyrocompass, EGNOS_GPSV - Differential GPS ( EGNOS corrections) \& compass GPS (CSI Vector),

EGNOSSA(nI)_GPSVP - Differential GPS ( EGNOS corrections) the Best case kompas GPS Vector (\& compass GPS (CSI Vector), (accuracy published by manufacturer),

RTK_2RTK - Real Time Kinematic GPS \& heading determined between two synchronically measuring DGPS receivers.

The logging possibility of ship's movement parameters during ship's trails gave an opportunity to collect the set of data required for statistical analysis. As a result of $21 \mathrm{~m} / \mathrm{f}$ "Jan Śniadecki" passages exiting the harbour, the probabilities of accident have been determined (Fig.4) for the searched configuration of INS and compared to the acceptable probability.

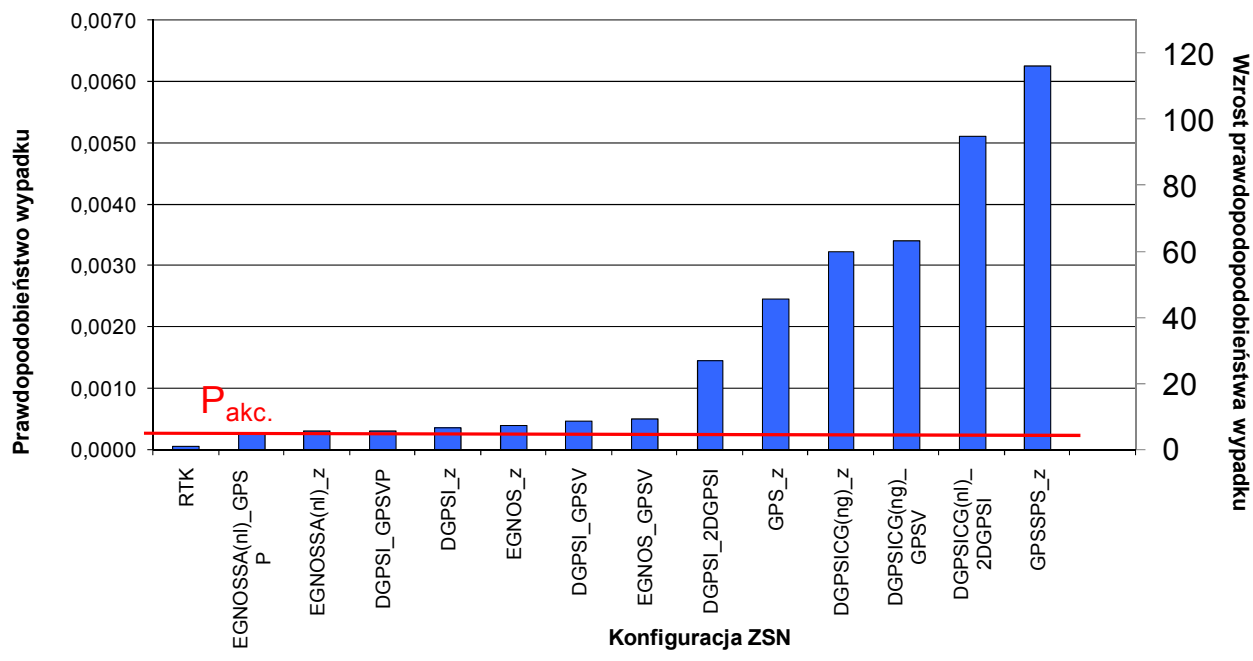

Fig. 4. Probability of navigation accident of $\mathrm{m} / \mathrm{f}$ “Jan Śniadecki” leaving Świnoujście near east head of breakwater considering the uncertainty area of ferry plan geometry. 
In all searched configuration variants probability of accident exceeded the acceptable probability value. The determined probability values are in the range between 0,00005 for "EGNOSSA(nl)_GPSVP" and 0,062 for "GPSSPS_z". The probability determined for common configurations of INS was: 0,0003 in "DGPSI_z" case, 0,0038 in "EGNOS_z" case and 0,062 "GPS_z" case.

The uncertainty of ship's plan geometry in INS causes the broadening of safe maneuvering area. Considering this the safety margin coefficient of safe maneuvering area was determined at a given confidence level for $\mathrm{m} / \mathrm{f}$ "Jan Śniadecki" maneuvering carried out on the basis of particular configuration of INS. Safety margin can be expressed according the below formula:

$$
S_{m}[\%]=\frac{S_{i}}{S_{w z}} 100 \%-100 \%
$$

where: $S_{i^{-}}$ship's safe maneuvering areas determined for particular configuration of INS,$S_{w z^{-}}$ship's maneuvering area determined for real ship's contour without uncertainty area allowance. The width of the maneuvering area in particular sections can be described by the sum of distances of extreme ship's waterplane outline points to the left and right of the reference fairway axis. Statistically, at the specified, confidence level, it can be defined by the following formula:

$$
d_{w s(c)}=\left(d_{s l a v}+k \sigma_{s l}\right)+\left(d_{s r a v}+k \sigma_{s r}\right)
$$

where: $d_{w s(c)}$-width of the manoeuvring area at $c$ confidence level in reference to the $s$-section point of the fairway axis, $d_{\text {slav }}, d_{\text {srav }}$-average distances of extreme ship's waterplane outline points to the left and right of the reference axis, $k$-coefficient dependent on accepted confidence level and $d_{s l}, d_{s r}$ variables' distribution (eg. $k \approx 2$ for normal distribution at confidence level 0.95$), \sigma_{s l}, \sigma_{s r}$-standard deviations of distances to the left and right of the reference axis.

The values of safety margins coefficients of safe maneuvering areas calculated for $\mathrm{m} / \mathrm{f}$ "Jan Śniadecki" are presented on figure 5. 


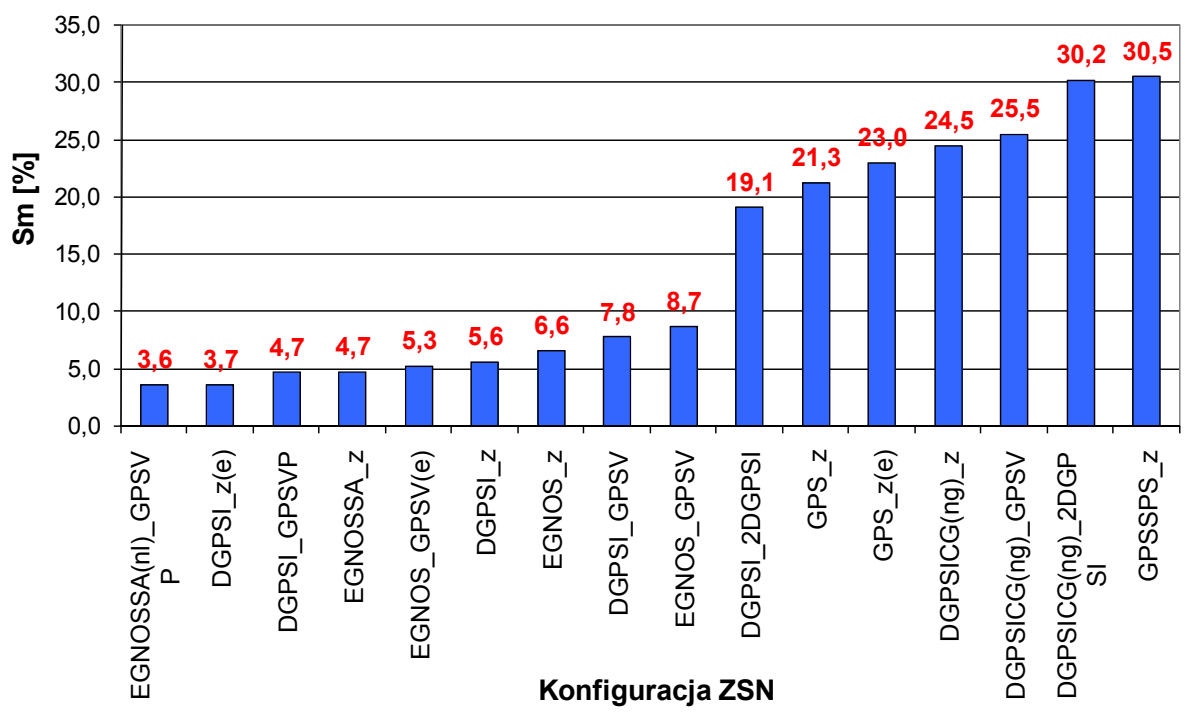

Fig. 5. The safety margin coefficient of $\mathrm{m} / \mathrm{f}$ „Jan Śniadecki” safe manoeuvring areas for different configurations of INS.

The conclusion is that maximum difference between safe manoeuvring areas obtained from studies without allowance for uncertainty area of ship's plan geometry and studies with such allowance can reach approximately $30 \%$ in Świnoujście harbour area for the "GPSSPS_z" configuration used. The determined safety margin coefficient values are in the range between 3,6\% for "EGNOSSA(nl)_GPSVP" and 30\% for "GPSSPS_z".

\section{Conclusions.}

The experiment performed has proved the necessity of uncertainty area of ship's plan geometry consideration in safety evaluation of manoeuvres carried out on based of INS. There are statistically significant differences in the manoeuvring area dimensions between different configuration of common navigation devices the INS is consisted of. That's why the method incorporating the idea to include probabilistic ship's contour dimensions is suggested to take precedence in the process of evaluation of manoeuvres safety. This method always requires preliminary research of the navigation system used or recommended in the studied area, but the resultant safety measures are more reliable. In the carried experiment the approx. 30\% difference in safety criterion was noted between measurement (RTK) 
method and uncertainty area inclusive method. The difference has been obtained also in probability of accident value (the increase of 120 ).

\section{References}

1. Tomczak A.: Analytical model of position uncertainty of ship's plan geometry in integrated navigation system; $7^{\text {th }}$ International Navigational Symposium "Trans-Nav", Gdynia 2007.

2. Tomczak A.: Effect of the Visualization of Position Uncertainty of Ship's Plan Geometry on the Safety of Navigation in Integrated Navigation Systems, XII Międzynarodowa Konferencja NaukowoTechniczna Inżynierii Ruchu Morskiego, Świnoujście 2007.

3. Gucma S. Navigation risk assessment as efficiency evaluation of waterway modernization.: Risk Analysis II, editor Brebbia C.A., WIT Press, Southampton 2000.

4. International Organization For Standardization: Guide to Expression of Uncertainty in Measurement, 1995.

5. Adamczewski Z.: Rachunek wyrównawczy, Oficyna Wydawnicza Politechniki Warszawskiej, Warszawa 2007. 


\section{OCENA BEZPIECZEŃSTWA MANEWRÓW STATKU WYKONANYCH NA PODSTAWIE WSKAZAŃ ZINTEGROWANEGO SYSTEMU NAWIGACYJNEGO (ZSN)}

\section{Wstęp}

Zintegrowane systemy nawigacyjne (ZSN) wykorzystywane są coraz częściej, jako podstawowe źródło informacji nawigacyjnej podczas ograniczonej widzialności. Nawigator analizuje zmiany w układzie statek środowisko $\mathrm{w}$ oparciu o wskazania systemu, bez możliwości prowadzenia obserwacji wzrokowej. W znacznej części, sytuacje tego typu zdarzają się na akwenach ograniczonych, na których istnieje podwyższone ryzyko wystapienia wypadku nawigacyjnego. Podstawową informacją prezentowaną $\mathrm{W}$ systemach nawigacyjnych jest graficzna prezentacja położenia statku w stosunku do niebezpieczeństw nawigacyjnych (rys.1). Ze względu na metodę określania położenia statku [1] jako obiektu geometrycznego w systemie nawigacyjnym, wykorzystującą wartości mierzone bezpośrednio (pozycja, kurs) położenie to obarczone jest niepewnością.

Obszar niepewności położenia statku jest to obszar zajmowany w poziomie przez statek, którego wymiary można określić metodami probabilistycznymi na przyjętym poziomie prawdopodobieństwa. Wielkość tego obszaru wyraża niepewność wyznaczania położenia statku w zintegrowanych systemach nawigacyjnych, a odległość jego granic w stosunku do niebezpieczeństw nawigacyjnych może stanowić kryterium oceny bezpieczeństwa manewrów wykonanych na podstawie wskazań systemu nawigacyjnego. 


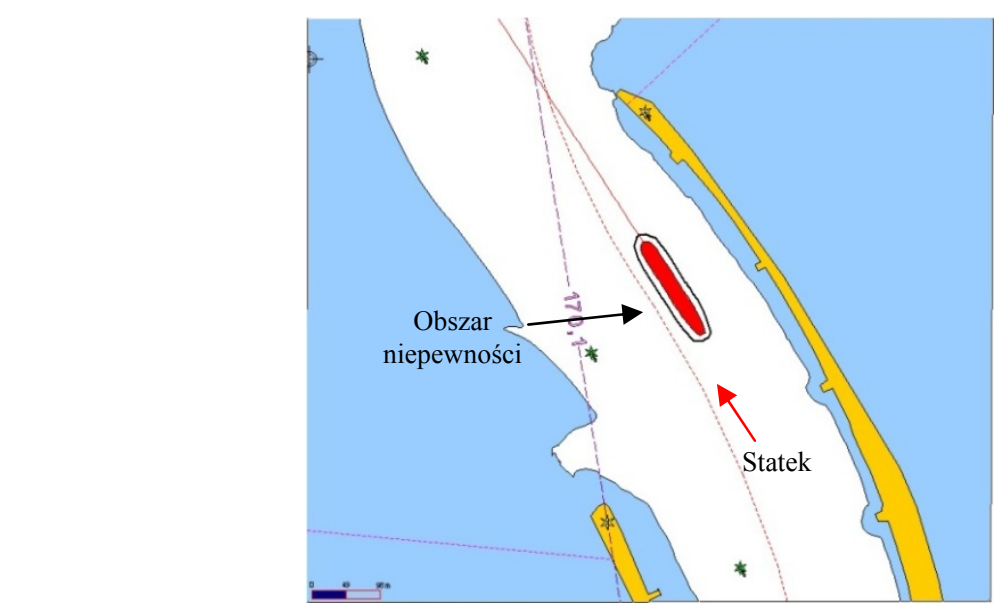

Rys. 1. Prezentacja statku w raz z obszarem niepewności jego położenia [2] w pilotowym systemie nawigacyjnym.

Biorąc pod uwagę zróżnicowanie ZSN w aspekcie wykorzystywanych technik pomiaru pozycji GPS (absolutne GPS, różnicowe DGPS, EGNOS i względne RTK) [1], kursu rzeczywistego (kompas GPS, żyrokompas) lub miejsca usytuowania anteny na pokładzie jednostki można wnioskować, że manewry wykonane na podstawie wskazań ZSN charakteryzują się różnym poziomem bezpieczeństwa. Interesująca $\mathrm{z}$ punktu widzenia oceny bezpieczeństwa manewrów jest zależność zmian podstawowych wskaźników bezpieczeństwa (wymiary bezpiecznego akwenu manewrowego i prawdopodobieństwo wypadku) dla manewrów wykonywanych na podstawie ZSN, od zmieniającej się konfiguracji sprzętowej i technik pomiarowych pozycji i kursu. Problem oceny bezpieczeństwa manewrów wykonanych na podstawie wskazań ZSN wydaje się być szczególnie aktualny $\mathrm{w}$ świetle prowadzonych badań i dyskusji podejmowanej w Unii Europejskiej nad możliwością zdalnego pilotażu statków [2].

\section{Model matematyczny obszaru niepewności położenia statku.}

Wyznaczenie położenia obwiedni statku w ZSN można traktować, jako pomiar złożony, którego model matematyczny opisują równania:

$$
\begin{aligned}
& x_{r i}=x_{A r i}+d_{i} \sin \left(\psi_{r i}+\alpha_{i}\right) \\
& y_{r i}=y_{A r i}+d_{i} \cos \left(\psi_{r i}+\alpha_{i}\right)
\end{aligned}
$$


gdzie: $x_{r i}, y_{r i}$-współrzędne kolejnych punktów, obwiedni wzorcowej statku, $x_{A r i}, y_{A r i}$ - współrzędne geograficzne w miejscu usytuowania anteny GPS, $\psi_{r i}$ -kurs rzeczywisty, $d_{i}$-odległości charakteryzujące wektory pomiędzy punktem, usytuowania anteny $P_{A}(0,0)$, a punktami skrajnymi obwiedni wzorcowej, $\alpha_{i}$-kierunki charakteryzujące wektory pomiędzy punktem, usytuowania anteny $P_{A}(0,0)$, a punktami skrajnymi obwiedni wzorcowej. Wymiary obszaru niepewności (rys. 1) położenia statku można określić na podstawie równań opisujących elipsę błędu położenia punktu [1],[5]:

$$
\begin{aligned}
& A_{1-\alpha}=A \sqrt{\chi_{2,1-\alpha}^{2}} \\
& B_{1-\alpha}=B \sqrt{\chi_{2,1-\alpha}^{2}}
\end{aligned}
$$

gdzie:

$$
\begin{aligned}
& A=\sigma\left(\alpha_{A}\right) \\
& B=\sigma\left(\alpha_{B}\right)
\end{aligned}
$$

Błąd położenia kolejnego punktu obwiedni statku w kierunku azymutu $(\alpha)$, zakreślający ze zmianą azymutu $(\alpha)$ krzywą błędu, dany jest wzorem:

$$
\sigma(\alpha)=\sqrt{\sigma x_{r i}^{2} \cos ^{2} \alpha+\sigma x_{r i} y_{r i} \sin 2 \alpha+\sigma y_{r i}^{2} \sin ^{2} \alpha}
$$

Azymuty $\alpha_{A}$ i $\alpha_{B}$ określono następująco:

$$
\begin{aligned}
& \alpha_{A}=\frac{1}{2} \arctan \left(\frac{2 \sigma x_{r i} y_{r i}}{\sigma x_{r i}^{2}-\sigma y_{r i}^{2}}\right) \\
& \alpha_{B}=\alpha_{A}+\frac{\pi}{2}
\end{aligned}
$$

gdzie: $\sigma x_{r i}^{2}$ wariancja współrzędnej x i-tego punktu obwiedni statku, $\sigma y_{r i}^{2}$ wariancja współrzędnej y i-tego punktu obwiedni statku, $\sigma x_{r i} y_{r i}-$ kowariancja współrzędnych (x, y) i-tego punktu obwiedni statku, $A$ - duża półoś elipsy położenia punktu, $B$ - mała półoś elipsy położenia punktu, Korzystając $\mathrm{z}$ ogólnej postaci prawa przenoszenia błędu, kowariancję $\sigma_{F}$ błędu funkcji obserwacji $x_{r i}$, $y_{r i}$ wyznaczyć można z następującej zależności [4]: 


$$
\sigma_{F}=\left[\begin{array}{llll}
\frac{\partial x_{r i}}{x_{A r i}} & \frac{\partial x_{r i}}{y_{A r i}} & \frac{\partial x_{r i}}{d_{i}} & \frac{\partial x_{r i}}{\gamma_{i}} \\
\frac{\partial y_{r i}}{y_{A r i}} & \frac{\partial y_{r i}}{x_{A r i}} & \frac{\partial y_{r i}}{d_{i}} & \frac{\partial y_{r i}}{\gamma_{i}}
\end{array}\right] \cdot\left[\begin{array}{cccc}
\sigma x_{A r i}^{2} & \sigma_{A r i} y_{A r i} & 0 & 0 \\
\sigma x_{A r i} y_{A r i} & \sigma y_{A r i}^{2} & 0 & 0 \\
0 & 0 & \sigma d_{i}^{2} & 0 \\
0 & 0 & 0 & \sigma \gamma_{i}^{2}
\end{array}\right] \cdot\left[\begin{array}{ll}
\frac{\partial x_{r i}}{x_{A r i}} & \frac{\partial y_{r i}}{y_{A r i}} \\
\frac{\partial x_{r i}}{y_{A r i}} & \frac{\partial y_{r i}}{x_{A r i}} \\
\frac{\partial x_{r i}}{d_{i}} & \frac{\partial y_{r i}}{d_{i}} \\
\frac{\partial x_{r i}}{\gamma_{i}} & \frac{\partial y_{r i}}{\gamma_{i}}
\end{array}\right]
$$

gdzie: $\sigma x_{A r i}^{2}$-wariancja współrzędnej długości geograficznej, $\sigma y_{A r i}^{2}-$ wariancja współrzędnej szerokości geograficznej, $\sigma x_{A r i} y_{A r i}$-kowariancja współrzędnych szerokości i długości pozycji geograficznej.

Stąd niepewności standardowe współrzędnych mierzonego punktu obwiedni $\left(\sigma x_{r i}, \sigma y_{r i}\right)$ i ich kowariancja $\sigma x_{r i} y_{r i}$ służące do wyznaczenia wektorów kierunkowych są równe:

$$
\begin{aligned}
& \sigma x_{r i}^{2}=\sigma x_{A r i}^{2}+\sigma d_{i}^{2} \sin ^{2} \gamma_{i}+\sigma \gamma_{i}^{2} d^{2} \cos ^{2} \gamma_{i} \\
& \sigma y_{r i}^{2}=\sigma y_{A r i}^{2}+\sigma d_{i}^{2} \cos ^{2} \gamma_{i}+\sigma \gamma_{i}^{2} d^{2} \sin ^{2} \gamma_{i} \\
& \sigma x_{r i} y_{r i}=\sigma x_{A r i} y_{A r i}+\sigma d_{i}^{2} \sin \gamma_{i} \cos \gamma_{i}-\sigma \gamma_{i}^{2} d_{i}^{2} \sin \gamma_{i} \cos \gamma_{i}
\end{aligned}
$$

Podstawiając do równan półosi elipsy obliczone wartości wariancji i kowariancji współrzędnych kolejnych punktów obwiedni kadłuba statku otrzymano jednostkowe wektory kierunkowe błędu położenia punktu obwiedni statku:

$$
\begin{aligned}
& \alpha_{A}=\frac{1}{2} \arctan \\
& \left(\frac{2\left(\sigma x_{A r i} y_{A r i}+\sigma d_{i}^{2} \sin \gamma_{i} \cos \gamma_{i}-\sigma \gamma_{i}^{2} d_{i}^{2} \sin \gamma_{i} \cos \gamma_{i}\right)}{\left(\sigma x_{A r i}^{2}+\sigma d_{i}^{2} \sin ^{2} \gamma_{i}+\sigma \gamma_{i}^{2} d^{2} \cos ^{2} \gamma_{i}\right)-\left(\sigma y_{A r i}^{2}+\sigma d_{i}^{2} \cos ^{2} \gamma_{i}+\sigma \gamma_{i}^{2} d^{2} \sin ^{2} \gamma_{i}\right)}\right), \\
& \alpha_{B}=\alpha_{A}+\frac{\pi}{2}
\end{aligned}
$$

Przykład obszaru niepewności wyznaczonego według powyższego algorytmu przedstawia rysunek 2 . 


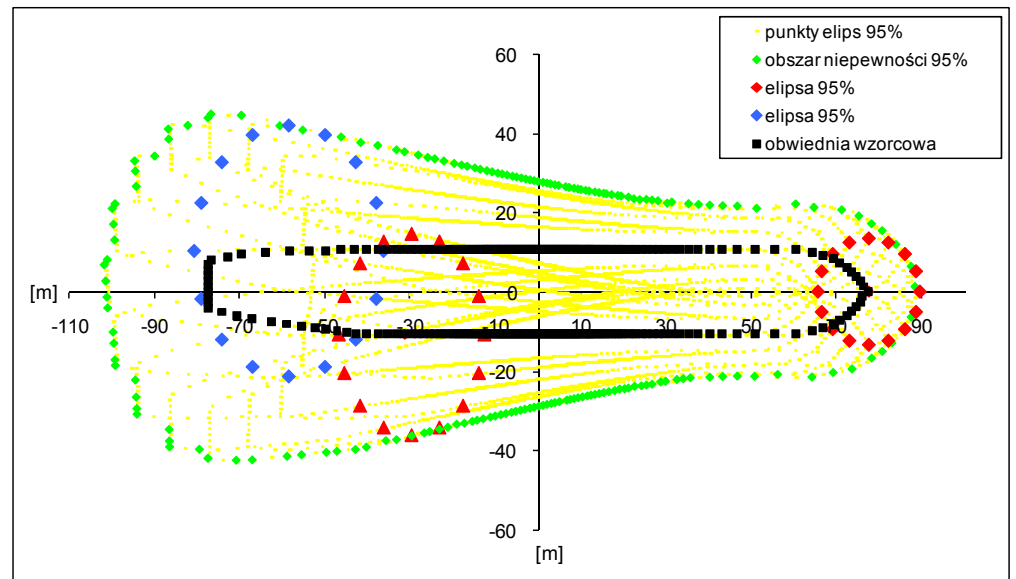

Rys. 2. Obszar niepewności położenia statku wokół obwiedni wzorcowej promu $\mathrm{m} / \mathrm{f}$ „Jan Śniadecki", utworzony po wyselekcjonowaniu skrajnych punktów elips błędów w przyjętych sektorach kątowych $\Delta \alpha$, dla poziomu ufności $95 \%$, antena w części dziobowej.

\section{Ocena bezpieczeństwa manewrów statku wykonanych na podstawie wskazań zintegrowanego systemu nawigacyjnego.}

Podczas wymiarowania ograniczonego akwenu najistotniejszym problemem jest bezpieczeństwo żeglugi na tym akwenie. Wymaga ono od projektanta podjęcia próby oszacowania ryzyka wypadku nazywanym również ryzykiem manewrowania, jakie będzie występowało podczas wykonywania określonego manewru statkiem na tym akwenie.

Ryzyko to jest definiowane, jako kombinacja prawdopodobieństwa wystapienia wypadku i skutków, jakie ten wypadek spowodował i można je opisać zależnością:

$$
R=P_{A} \cdot S_{a}
$$

gdzie: $S_{a^{-}}$skutki spowodowane przez wypadek.

W badaniach przyjęto wartość ryzyka na poziomie $R=0,07$. Prawdopodobieństwo akceptowalne wyniosło $P_{a k c .}=0,00019444, \quad$ a wyznaczono je w oparciu o następującą zależność: 


$$
P_{a k c .}=\frac{R_{a k c}}{I_{R} S_{a}}
$$

gdzie: $R_{a k c^{-}}$akceptowalne ryzyko wypadku, $I_{R^{-}}$średnia roczna intensywność wykonania danego manewru (np. wyjścia z portu).

Ocena bezpieczeństwa manewrów obejmowała wyznaczenie prawdopodobieństw wypadku i szerokości akwenów manewrowych promu m/f ,Jan Śniadecki” manewrującego na podstawie wskazań ZSN, w porcie Świnoujście. Wypadek polegał na przekroczeniu przez prom bezpieczniej izobaty „8m" podczas wyjścia z portu. Prawdopodobieństwo wypadku badano na wysokości wschodniej główki falochronu, zmieniając konfigurację sprzętową ZSN.

Wskaźniki bezpieczeństwa wyznaczono na podstawie 21 rzeczywistych manewrów wyjścia promu $\mathrm{z}$ portu, $\mathrm{z}$ wykorzystaniem obszarów niepewności jego położenia $\mathrm{w}$ ZSN. Warianty wykorzystujące parametry wejściowe dokładności pozycji i kursu zweryfikowane w eksperymencie rzeczywistym opisano bez dodatkowych oznaczeń np. „GPS_z” jako: GPS autonomiczny i żyrokompas. W pozostałych wariantach stosowano dodatkowe oznaczenia. Poszczególne nazwy wariantów oznaczają:

GPS_z - GPS autonomiczny i żyrokompas,

GPSSPS_z - GPS autonomiczny (dokładność publikowana przez Standard Positioning Service - SPS) i żyrokompas,

DGPSI_z - Różnicowy system GPS i żyrokompas,

DGPSICG(ng)_z - Różnicowy system GPS (dokładność publikowana przez American Coast Guard - dla najniekorzystniejszej lokalizacji odbiornika względem stacji referencyjnej) i żyrokompas,

DGPSI_GPSV - Różnicowy system GPS i kompas GPS Vector, DGPSICG(ng)_GPSV - Różnicowy system GPS (American Coast Guard dla najniekorzystniejszej lokalizacji odbiornika względem stacji referencyjnej) i kompas GPS Vector,

DGPSI_GPSVP - Różnicowy system GPS i kompas GPS Vector (dokładność publikowana przez producenta kompas GPS),

DGPSI_2DGPSI - Różnicowy system GPS i kurs określany między dwoma synchronicznie pracującymi odbiornikami DGPSI,

DGPSICG(nl)_ 2DGPSI - Różnicowy system GPS wykorzystujący poprawki ze stacji referencyjnej IALA (dokładność publikowana przez American Coast Guard - Straż Wybrzeża USA dla najkorzystniejszej lokalizacji odbiornika względem stacji referencyjnej) i kurs określany 
między dwoma synchronicznie pracującymi odbiornikami DGPSI ze stacją różnicową w Dziwnowie,

EGNOS_z - Różnicowy system GPS wykorzystujący poprawki systemu EGNOS i żyrokompas,

EGNOSSA(nl)_z - Różnicowy system GPS wykorzystujący poprawki systemu EGNOS (zakładana dokładność publikowana przez -Europejską Agencję kosmiczną $\mathrm{z}$ ang.: ESA dla najkorzystniejszego położenia odbiornika) i żyrokompas,

EGNOS_GPSV - Różnicowy system GPS wykorzystujący poprawki systemu EGNOS i kompas GPS Vector,

EGNOSSA(nI)_GPSVP - Różnicowy system GPS wykorzystujący poprawki systemu EGNOS dla najkorzystniejszego położenia odbiornika i kompas GPS Vector (dokładność producenta kompasu GPS),

RTK_2RTK - Różnicowy system kinematyczny wykorzystujący poprawki ze stacji bazowej RTK i kurs określany między dwoma synchronicznie pracującymi odbiornikami RTK.

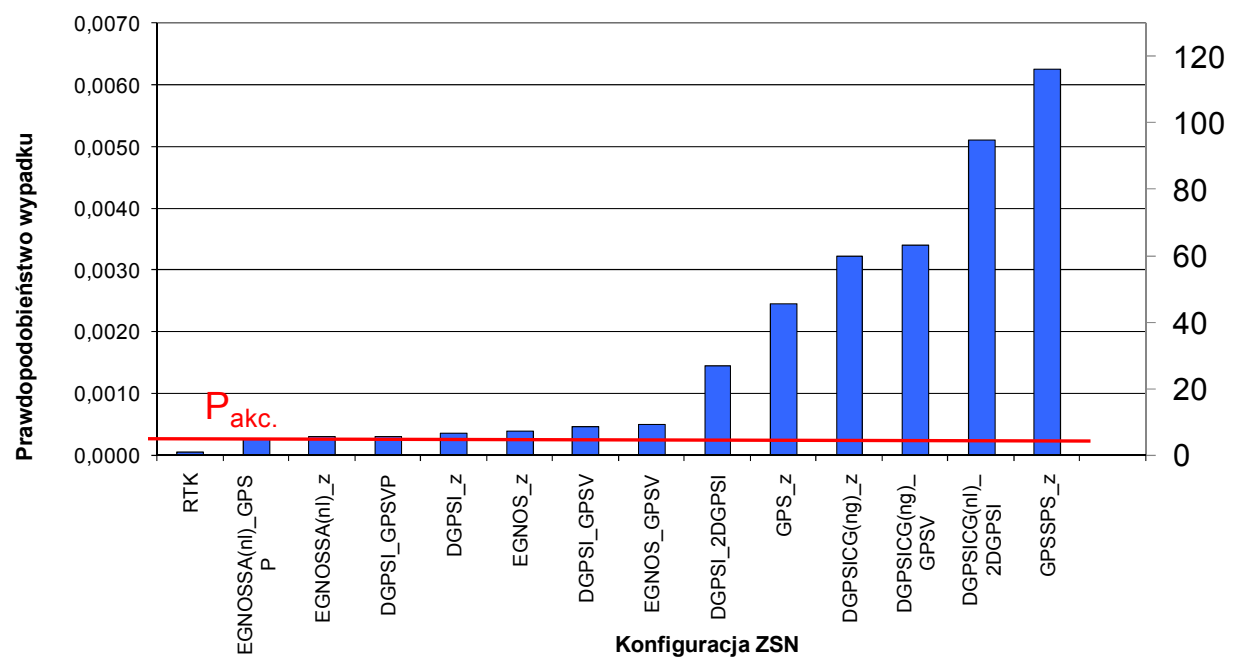

Rys.3. Prawdopodobieństwo przekroczenia izobaty „8m” oraz wzrost prawdopodobieństwa wypadku określone z uwzględnieniem niepewności położenia dla różnych konfiguracji systemu nawigacyjnego, obliczone dla promu m/f „Jan Śniadecki”, wychodzącego z portu Świnoujście.

We wszystkich badanych przypadkach konfiguracyjnych (z uwzględnieniem niepewności położenia statku) poziom wyznaczonego prawdopodobieństwa przekroczył wartość prawdopodobieństwa 
akceptowalnego. Zakres wartości obliczonych prawdopodobieństw maksymalnych mieści się $\mathrm{W}$ przedziale od 0,00005 dla wariantu „EGNOSSA(nl)_GPSVP” do 0,062 dla wariantu „GPSSPS_z”). Dla najpowszechniej stosowanych wariantów konfiguracyjnych prawdopodobieństwo wynosiło $0,0003 \mathrm{w}$ przypadku DGPS IALA i żyrokompasu, 0,0038 w przypadku EGNOS i żyrokompasu i $0,062 \mathrm{w}$ przypadku GPS (autonomiczny i żyrokompas).

Niepewność położenia statku manewrującego na podstawie wskazań sytemu nawigacyjnego powoduje zwiększenie szerokości jego akwenu manerowego. W związku $\mathrm{z}$ tym wyznaczono procentowy współczynnik poszerzenia akwenu manewrowego $\left(S_{m}\right)$ statku na przyjętym poziomie ufności $(0,95)$ dla statku, manewrującego na podstawie wskazań systemu nawigacyjnego, w danej konfiguracji sprzętowej. Procentowy współczynnik poszerzenia akwenu manewrowego obliczono, jako stosunek szerokości akwenu wyznaczonego dla danego systemu nawigacyjnego (dla obszaru niepewności położenia wyznaczonego analitycznie) na przyjętym poziomie ufności, do szerokości akwenu wyznaczonego dla obwiedni wzorcowej (rzeczywistej) statku pomnożonej przez 100\% minus 100\%, na podstawie następującej zależności:

$$
S_{m}[\%]=\frac{S_{i}}{S_{w z}} 100 \%-100 \%
$$

gdzie: $S_{i^{-}}$szerokość akwenu manewrowego wyznaczona dla obszaru niepewności położenia statku, $S_{w z^{-}}$szerokość akwenu manewrowego wyznaczona dla obwiedni wzorcowej (rzeczywistej). Szerokość akwenu manewrowego można wyrazić, jako sumę odległości skrajnych punktów obwiedni statku na lewo i prawo od osi odniesienia (oś toru wodnego).

Statystycznie obliczona szerokość akwenu manewrowego, na przyjętym poziomie ufności wyraża się równaniem:

$$
d_{w s(c)}=\left(d_{s l a v}+k \sigma_{s l}\right)+\left(d_{s r a v}+k \sigma_{s r}\right)
$$

where: $d_{w s(c)}$-szerokość akwenu manewrowego dla przyjętego poziomu ufności, $d_{\text {slav }}, d_{\text {srav }}$-średnie odległości skrajnych punktów obwiedni statku na lewo i prawo od osi toru, $k$-współczynnik rozszerzenia zależny od przyjętego poziomu ufności, $\sigma_{s l}, \sigma_{s r^{-}}$odchylenie standardowe zmiennej losowej odległości skrajnych punktów obwiedni statku na lewo i prawo od osi toru wodnego. 
Wartości procentowych współczynników poszerzenia akwenu manewrowego statku dla opisanych konfiguracji sprzętowych systemu nawigacyjnego przedstawia rysunek 4 . Wartości współczynników zawierają się w przedziale o 3,6\%, dla konfiguracji „EGNOSSA(nl)_GPSVP” do 30,5 dla wariantu „GPSSPS_z”.

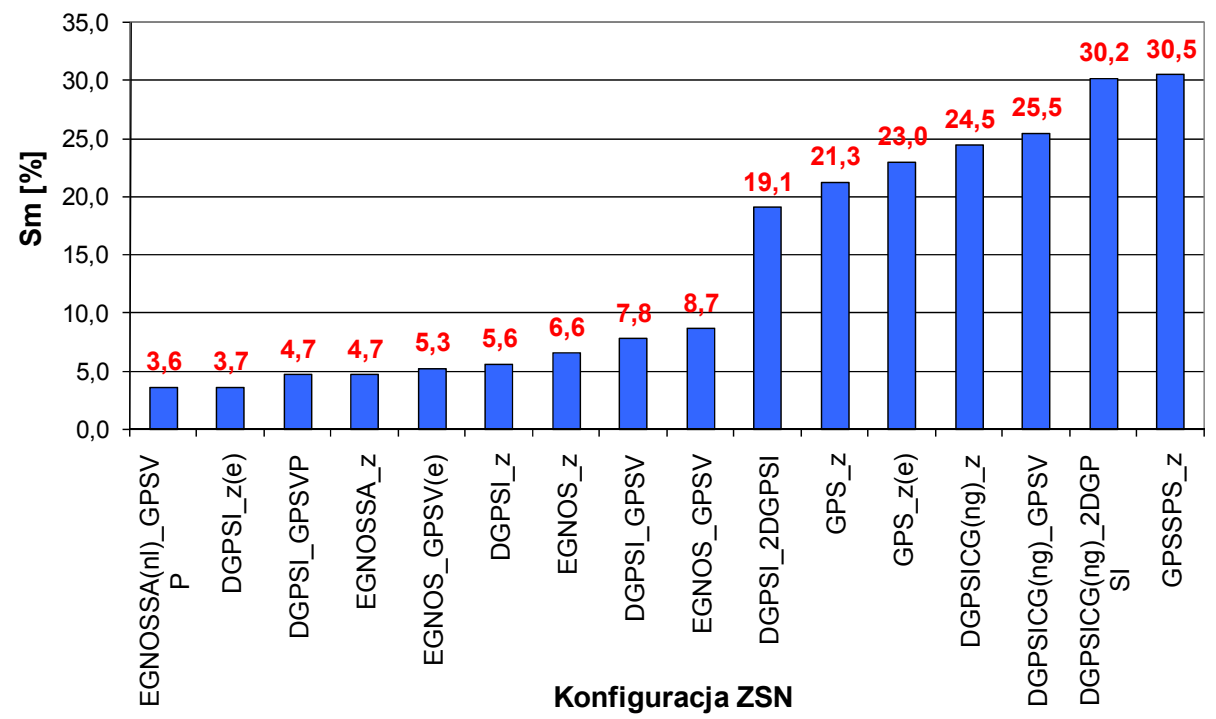

Rys. 4. Wartość procentowego współczynnika poszerzenia pasa ruchu statku dla badanych konfiguracji systemu nawigacyjnego.

\section{Wnioski}

$\mathrm{W}$ artykule przedstawiono ocenę bezpieczeństwa manewrów promu $\mathrm{m} / \mathrm{f}$ „Jan Śniadecki” wykonanych na podstawie wskazań ZSN w opraciu o kryteria prawdopodobieństwa wypadku i szerokości akwenu manewerowego. W przeprowadzonych badaniach wykorzystano matematyczny model obszaru niepewności położenia statku w ZSN. Wyznaczono obszary niepewności położenia dla typowych, możliwych konfiguracji sprzętowych podsystemu nawigacyjnego uwzględniając między innymi zmianę techniki pozycjonowania GPS, wyznaczania kursu rzeczywistego. Na podstawie wyznaczonych obszarów niepewności wyznaczono szerokości akwenu manewrowego promu m/f „Jan Śniadecki” oraz prawdopodobieństwo wypadku polegające na przekroczeniu izobaty „8m”. Wskaźniki te porównano do wskaźników wyznaczonych dla manewrów wykonanych konwencjonalnie, bez wykorzystania ZSN. W 
wyniku porównania wykazano, że celowym jest uwzględnienie marginesu bezpieczeństwa $\mathrm{w}$ zajmowanym akwenie manewrowym statku - do 30\% jego szerokości oraz występującym prawdopodobieństwie wypadku wzrost do 120 razy.

Arkadiusz Tomczak is research and teaching employee of Szczecin Maritime University (MSc). His main scientific interest involves ship positioning methods with GPS system implementation in integrated navigational systems. He plans to finalize his $\mathrm{PhD}$ thesis titled "Multiconditional Assessment of Position of Ship's Plan Geometry in Integrated Navigation Systems" in 2008. He is the author of 16 scientific publications. 